\title{
ORGANIC FERTILIZERS ARE EFFECTIVE IN INCREASING GROWTH AND PRODUCTIVITY OF SHALLOT LEMBAH PALU VARIETIES
}

\author{
Bahrudin $^{1)}$, Muhammad Ansar ${ }^{1)}$ Abdul Rahim Thaha ${ }^{1)}$ \\ 1) Agrotechnology Study Program at the Faculty of Agriculture, Tadulako University \\ Kampus Bumi Tadulako, Jl. Soekarno Hatta KM. 9 Palu Sulawesi Tengah, Email :apasigai@ yahoo.com
}

\begin{abstract}
Shallot 'lembah palu' variety is the main raw material for fried onion industry in Central Sulawesi. This study aims to examine the LEISA technology package through the use of liquid and solid organic fertilizers from agricultural waste in order to obtain the quality of shallot bulbs that are good as raw material for fried onions. Research using Randomized Complete Block Design (RCBD) was repeated 4 (four) times. Treatment consists of: $(A)=$ without organic fertilizer; $(B)=$ liquid organic fertilizer (Biourin $40 \mathrm{~mL} / \mathrm{L}$ of water); $(\mathrm{C})=$ solid organic fertilizer (bokashi goat manure 20 ton/ha); $(\mathrm{D})=$ solid organic fertilizer (bokashi goat manure $10 \mathrm{ton} / \mathrm{ha})+$ liquid organic fertilizer (Biourin $20 \mathrm{~mL} / \mathrm{L}$ of water); $(\mathrm{E})=$ solid organic fertilizer (bokashi goat manure $20 \mathrm{ton} / \mathrm{ha}$ ) + liquid organic fertilizer (Biourin $40 \mathrm{~mL} / \mathrm{L}$ of water); $(\mathrm{F})=$ solid organic fertilizer $(20 \mathrm{ton} / \mathrm{ha}$ bokashi mixture of goat manure and shallot residues); $(\mathrm{G})=$ solid organic fertilizer $20 \mathrm{ton} / \mathrm{ha}$ bokashi mixture of goat manure and shallot residues)+liquid organic fertilizer (Biourin $30 \mathrm{~mL} / \mathrm{L}$ of water); $(\mathrm{H})=$ solid organic 10 ton/ha bokashi mixture of goat manure and shallot residues)+liquid organic fertilizer (Biourin $60 \mathrm{~mL} / \mathrm{L}$ of water; and $(\mathrm{I})=$ solid organic fertilizer $30 \mathrm{ton} / \mathrm{ha}$ bokashi mixture of goat manure and shallot residues)+ liquid organic fertilizer (Biourin $60 \mathrm{~mL} / \mathrm{L}$ of water). The results of the study were (i) the combination of types and doses of organic fertilizer in general resulted in higher growth and yield of shallots compared to without organic fertilizers, and (ii) a combination of solid organic fertilizer (mixture 20 ton/ha bokashi goat manure and shallot residue), produce number of leaves, leaf dry weight, fresh weight per tuber, and fresh weight of tuber per hectare higher than without organic fertilizer.
\end{abstract}

Keywords: LEISA, Lembah Palu, Organic Fertilizer, Shallot .

\section{INTRODUCTION}

In Central Sulawesi, there is shallot known as the 'lembah palu' variety which are the main raw materials of the fried onion industry, with very good quality because they have a distinctive texture, taste and aroma and are resistant to being stored for long periods with good packaging.

Fried onions from Palu are in great demand by regional and export markets, but the demand cannot be fulfilled because of the quantity, quality and continuity of products that cannot be guaranteed sustainably. The quantity of production cannot be guaranteed because the productivity of shallots 'lembah palu' is still low, which is an average of 3.5-4.5 ton/ha (BPTP Sulteng, 2004). The application of environmental modification technology to the use of plastic hoods and mulch (plastics and rice straw) can increase the yield of 'lembah palu' shallots to an average of 7.6 ton/ha (Ansar et al., 2013a), but these results are still lower than the potential yield of shallots that can reach 9.7 tons/ha (Mentan, 2011).

In general, the shallot 'lembah palu' still uses conventional technology with input from factory-made fertilizers and pesticides (agrochemicals) which has an impact on decreasing the quality of onion products, especially for fried onion raw materials. The use of agrochemicals such as 
fertilizers and pesticides made in factories that contain a lot of residues that can have a negative impact on health and the environment (Sutanto, 2002).

One of the inputs that needs to be developed in the cultivation of shallots 'lembah palu); is the use of organic fertilizers either in the form of solids or in liquid form. The application of LEISA technology that is oriented to the maximum utilization of local resources by utilizing organic materials available around agricultural land as input for crop cultivation, can overcome the negative impacts of using higher agrochemical inputs.The ecological principle that forms the basis of the LEISA system is to secure soil conditions suitable for plant growth by managing organic matter, optimizing nutrient availability, balancing nutrient flows, and minimizing nutrient losses and exploiting the use of complementary and synergetic genetic resources (Cao and Min, 1995).

Shallot 'lembah palu' if cultivated in the lowlands $(100 \mathrm{~m}$ above sea level (asl))with an average air temperature of $30^{\circ} \mathrm{C}$ requires $100 \%$ soil moisture capacity (Ansar, 2012). Thus the use of organic fertilizers can increase the ability of the soil to bind water and maintain a longer moisture content in the area of plant roots. The use of organic fertilizer is more beneficial than inorganic fertilizer because it does not cause residual organic acids in the soil and does not damage the soil if given excessively (Indiani, 2001). Increasing the content of organic matter in the soil will also increase the nutrient content of $\mathrm{N}, \mathrm{P}$ and $\mathrm{K}$ in the soil, so it can help the process of growth and increase crop yields (Adrizal and Jalid, 1995). Nutrients in the soil are available in sufficient quantities and absorption of nutrients in sufficient quantities is able to increase the process of fast photosynthesis which indirectly will affect the increase in growth and crop yields (Gardner et al., 1991).

Liquid organic fertilizer is organic fertilizer that comes from various types of materials, including crop residues and manure and green manure, where the application is dissolved in water (Yang, 2001). The advantages of liquid organic fertilizers are that they contain certain substances such as microorganisms which are rarely found in solid organic fertilizers, can also quickly overcome nutrient deficiency, have no problems in nutrient washing and are able to provide nutrients quickly (Sukamto, 2007).

This study aims to increase the growth and productivity of shallot tubers verieties of 'lembah palu' through the application of types and doses of solid organic fertilizer (livestock manure and shallots) and the addition of liquid organic fertilizer (Biourin) derived from fermented cattle manure.

\section{MATERIALS AND METHOD}

This research was conducted in April-November 2018, on farmer land in Sidera Village, Sigi-Biromaru District, Sigi Regency.

Research using Randomized Complete Block Design (RCBD) with4 (four) block. Treatment consists of: $(\mathrm{A})=$ without organic fertilizer; $(\mathrm{B})=$ liquid organic fertilizer (Biourin $40 \mathrm{~mL} / \mathrm{L}$ of water); $(\mathrm{C})=$ solid organic fertilizer (bokashi goat manure 20 ton/ha); (D)= solid organic fertilizer (bokashi goat manure 10 ton/ha) + liquid organic fertilizer (Biourin $20 \mathrm{~mL} / \mathrm{L}$ of water); $(\mathrm{E})=$ solid organic fertilizer (bokashi goat manure 20 ton/ha)+liquid organic fertilizer (Biourin $40 \mathrm{~mL} / \mathrm{L}$ of water); $(\mathrm{F})=$ solid organic fertilizer (20 ton/ha bokashi mixture of goat manure and shallot residues); $(\mathrm{G})$ = solid organic fertilizer 20 ton/ha bokashi mixture of goat manure and shallot residues) + liquid organic fertilizer (Biourin $30 \mathrm{~mL} / \mathrm{L}$ of water); $(\mathrm{H})=$ solid organic fertilizer10 ton/ha bokashi mixture of goat manure and shallot residues) + liquid organic fertilizer (Biourin $60 \mathrm{~mL} / \mathrm{L}$ of water; and $(\mathrm{I})=$ solid organic fertilizer 30 ton/ha bokashi mixture of goat manure and shallot residues)+liquid organic fertilizer (Biourin $60 \mathrm{~mL} / \mathrm{L}$ of water). 
Table 1. Effect of Combination of Types and doses of Fertilizer on The Number of Shallots Leaves Varieties of 'Lembah Palu'

\begin{tabular}{ccccc}
\hline \multirow{2}{*}{ Treatment } & \multicolumn{4}{c}{ Number of shallot leaves (sheet) at days after planting } \\
\cline { 2 - 5 } & $20 \mathrm{DAP}$ & $30 \mathrm{DAP}$ & $40 \mathrm{DAP}$ & $50 \mathrm{DAP}$ \\
\hline $\mathrm{A}$ & $10.25 \mathrm{~b}$ & $12.50 \mathrm{~b}$ & $15.30 \mathrm{~b}$ & $18.23 \mathrm{c}$ \\
$\mathrm{B}$ & $13.35 \mathrm{ab}$ & $17.96 \mathrm{a}$ & $20.60 \mathrm{ab}$ & $20.90 \mathrm{ab}$ \\
$\mathrm{C}$ & $11.88 \mathrm{ab}$ & $14.45 \mathrm{ab}$ & $16.85 \mathrm{ab}$ & $19.90 \mathrm{bc}$ \\
$\mathrm{D}$ & $11.85 \mathrm{ab}$ & $14.90 \mathrm{ab}$ & $18.45 \mathrm{ab}$ & $19.66 \mathrm{bc}$ \\
$\mathrm{E}$ & $13.90 \mathrm{a}$ & $17.95 \mathrm{a}$ & $22.85 \mathrm{a}$ & $25.69 \mathrm{ab}$ \\
$\mathrm{F}$ & $12.65 \mathrm{ab}$ & $17.75 \mathrm{a}$ & $22.85 \mathrm{a}$ & $26.74 \mathrm{a}$ \\
$\mathrm{G}$ & $12.25 \mathrm{ab}$ & $15.35 \mathrm{ab}$ & $19.35 \mathrm{ab}$ & $22.51 \mathrm{abc}$ \\
$\mathrm{H}$ & $13.60 \mathrm{ab}$ & $17.60 \mathrm{a}$ & $22.90 \mathrm{a}$ & $24.08 \mathrm{abc}$ \\
$\mathrm{I}$ & $14.80 \mathrm{a}$ & $19.14 \mathrm{a}$ & $24.05 \mathrm{a}$ & $25.32 \mathrm{ab}$ \\
\hline Tukey $\alpha 0.05$ & 3.60 & 5.06 & 7.26 & 6.08 \\
\hline
\end{tabular}

Description: Numbers followed by the same letters in the same column, are not significantly different $(\mathrm{P}<0.05)$ using tukey range test.

The size of the experimental plot in the field is $105 \mathrm{~cm}$ widthx $255 \mathrm{~cm}$ long x 25 $\mathrm{cm}$ high. The population of shallots is 119 plants per plot or spacing of $15 \mathrm{~cm} \times 15 \mathrm{~cm}$. The previously planted tubers are sterilized by mixing the seeds with a Dithane-M45 fungicide solution with a concentration of $25 \mathrm{~g} / 10$ liters of water, for 10-20 minutes. To maintain plant nutrient availability, the basic fertilizer is NPK compound fertilizer $(15: 15: 15)$ as much as $150 \mathrm{~kg} / \mathrm{ha}$ (Ansaret. al., 2014). Furthermore, to maintain temperature and soil moisture fluctuations in the variety of shallot varieties plantations "lembah palu" is covered by black plastic mulch (Ansaret. al., 2013b).

Solid organic fertilizers from bokashi goat manure and bokashi combination of goat manure and shallot plant waste were spread evenly on a trial plot with doses according to the treatment of each experimental plot. Giving organic fertilizer is carried out 2 weeks before planting shallots. The application of liquid organic fertilizer (biourin) was carried out at the ages of $15,25,35,45$ and 55 days after planting, while the concentration was adjusted according to treatment in each experimental plot. Prevention of pests and diseases is carried out by spraying Trichoderma sp. every 2 weeks until the plants are 55 days after planting.
The observed parameters were the growth components observed from 5 (five) sample plants in each trial plot, including the number of leaves, total dry weight per plant, and total leaf area per plant calculated using the gravimetric method according to the Khandakar (1994), ie Leaf Area = Leaf area of sample / leaf dry weight of sample $\mathrm{x}$ leaf dry weight per plant. The yield component was observed by taking 10 (ten) sample plants in each trial plot, to find out the number of tubers per clump, tuber diameter and length, fresh weight per tuber, and fresh tuber yield per hectare.

Analysis of observational data was carried out using analysis of variance, followed by the Tukey range analysis to compare differences between treatments according to Gomez and Gomez (1995).

\section{RESULTS AND DISCUSSION}

Number of Leaves. Various combinations of fertilizer types and doses significantly affected the number of leaves per plant shallot "lembah palu" variety at the age of 20-50 DAP (days after planting).

In Table 1 it is showed that treatment $\mathrm{E}$ (bokashi goat manure 20 ton/ha+liquid organic fertilizer (Biourin) 40 $\mathrm{mL} / \mathrm{L}$ of water) produces the highest number of leaves and is significantly different from treatment A (without organic 
fertilizer), but not significantly different from other treatments at the age of 20, 30 and 40 DAP.At the age of 50 days after planting, treatment $\mathrm{F}$ (mixture of goat manure and shallot waste as much as 20 ton/ha) produces the highest number of leaves and is significantly different from treatment A (without organic fertilizer), but not significantly different from other treatments, except with treatments $\mathrm{C}$ and $\mathrm{D}$.

Total Dry Weight Per Plant. The combination of various types and dosages of organic fertilizer significantly affected the total dry weight of the shallot varieties of the 'lembah palu' plant at the age of 2050 days after planting. In Table 2 it is shown that treatment $\mathrm{E}$ (bokashi goat manure 20 ton/ha+liquid organic fertilizer (Biourin) $40 \mathrm{~mL} / \mathrm{L}$ of water produces a higher total dry weight per plant and significantly different from controls at the age of 20-40 days after planting. At the age of 50 days after planting, E treatment (goat manure 20 ton/ha+liquid organic fertilizer (Biourin) $40 \mathrm{~mL} / \mathrm{L}$ of water produced the highest total dry weight per plant and significantly different from treatment D (goat manure 10 ton/ha+liquid organic fertilizer (Biourin) $20 \mathrm{~mL} / \mathrm{L}$ of water), but not significantly different from other treatments.
Total leaf area. Various combinations of types and dosages of organic fertilizers significantly influence the total leaf area of shallot 'lembah palu' varieties. At the age of 30-50 days after planting, but not significantly at the age of 20 days. Table 3 shows that at the age of 30, 40 and 50 days after planting, treatment $\mathrm{E}$ (bokashi goat manure 20 ton/ha+liquid organic fertilizer (Biourin) $40 \mathrm{~mL} /$ Lof water, produces the highest total leaf area per plant, conversely in treatment A (without fertilizer organic) obtained the lowest total leaf area per plant. The leaf surface area will be strongly related to the area of photosynthesis, so that the wider leaf area will cause photosynthesis to increase and dry matter production will increase, thereby increasing plant growth and yield.

Number of tubers per clumps. The treatment of various combinations of types and doses of fertilizers had a significant effect on the number of tubers per clumps of shallot 'lembah palu' variety. In Table 5 it is shown that treatment $\mathrm{B}$ (liquid organic fertilizer (Biourin) $40 \mathrm{~mL} / \mathrm{L}$ of water) produces the highest number of tubers per clump (7.20 pieces) and is significantly different from treatment $\mathrm{A}$ (without organic fertilizer), but not significantly different from treatment others.

Table 2. Effect of Combination of Type and Dosage of Organic Fertilizer on Total Dry Weight per plant

\begin{tabular}{ccccc}
\hline \multirow{2}{*}{ Treatment } & \multicolumn{4}{c}{$\begin{array}{c}\text { Total dry weight (g/plant) of shallot, } \\
\text { at days after planting }\end{array}$} \\
\cline { 2 - 5 } & $20 \mathrm{DAP}$ & $30 \mathrm{DAP}$ & $40 \mathrm{DAP}$ & $50 \mathrm{DAP}$ \\
\hline $\mathrm{A}$ & $0.12 \mathrm{~b}$ & $0.27 \mathrm{c}$ & $0.46 \mathrm{c}$ & $1.31 \mathrm{ab}$ \\
$\mathrm{B}$ & $0.23 \mathrm{a}$ & $0.27 \mathrm{c}$ & $0.66 \mathrm{abc}$ & $1.38 \mathrm{ab}$ \\
$\mathrm{C}$ & $0.17 \mathrm{ab}$ & $0.34 \mathrm{c}$ & $0.63 \mathrm{bc}$ & $1.26 \mathrm{ab}$ \\
$\mathrm{D}$ & $0.19 \mathrm{ab}$ & $0.42 \mathrm{bc}$ & $0.74 \mathrm{abc}$ & $1.07 \mathrm{~b}$ \\
$\mathrm{E}$ & $0.23 \mathrm{a}$ & $0.61 \mathrm{ab}$ & $1.04 \mathrm{a}$ & $1.79 \mathrm{a}$ \\
$\mathrm{F}$ & $0.23 \mathrm{ab}$ & $0.69 \mathrm{a}$ & $0.99 \mathrm{ab}$ & $1.51 \mathrm{ab}$ \\
$\mathrm{G}$ & $0.15 \mathrm{ab}$ & $0.37 \mathrm{c}$ & $0.91 \mathrm{ab}$ & $1.40 \mathrm{ab}$ \\
$\mathrm{H}$ & $0.19 \mathrm{ab}$ & $0.41 \mathrm{bc}$ & $0.74 \mathrm{abc}$ & $1.48 \mathrm{ab}$ \\
$\mathrm{I}$ & $0.15 \mathrm{ab}$ & $0.32 \mathrm{c}$ & $0.81 \mathrm{abc}$ & $1.26 \mathrm{ab}$ \\
\hline
\end{tabular}

Description: Numbers followed by the same letters in the same column, are not significantly different $(\mathrm{P}<0.05)$ using tukey range test. 
Table 3. Effect of Combination of Type and Dosage of Organic Fertilizer on Total Leaf Area Per Shallot Plant

\begin{tabular}{ccccc}
\hline \multirow{2}{*}{ Treatment } & \multicolumn{5}{c}{ Total leaf area $\left(\mathrm{cm}^{2} /\right.$ plant $)$ shallot varieties of 'lembah palu' at days } \\
& \multicolumn{4}{c}{ after planting } \\
\cline { 2 - 5 } & $20 \mathrm{DAP}$ & $30 \mathrm{DAP}$ & $40 \mathrm{DAP}$ & $50 \mathrm{DAP}$ \\
\hline $\mathrm{A}$ & 120.8 & $405.7 \mathrm{~b}$ & $643.9 \mathrm{~b}$ & $809.5 \mathrm{~b}$ \\
$\mathrm{~B}$ & 138.2 & $564.5 \mathrm{~b}$ & $899.5 \mathrm{~b}$ & $1,657.6 \mathrm{ab}$ \\
$\mathrm{C}$ & 125.6 & $524.4 \mathrm{~b}$ & $857.5 \mathrm{~b}$ & $1,630.4 \mathrm{ab}$ \\
$\mathrm{D}$ & 146.7 & $601.6 \mathrm{~b}$ & $877.6 \mathrm{~b}$ & $1,409.6 \mathrm{ab}$ \\
$\mathrm{E}$ & 144.7 & $1,056.7 \mathrm{a}$ & $1,681.9 \mathrm{a}$ & $2,284.4 \mathrm{a}$ \\
$\mathrm{F}$ & 162.6 & $800.4 \mathrm{ab}$ & $1,189.5 \mathrm{ab}$ & $2,149.2 \mathrm{a}$ \\
$\mathrm{G}$ & 132.6 & $727.3 \mathrm{ab}$ & $1,237.8 \mathrm{ab}$ & $1,916.5 \mathrm{a}$ \\
$\mathrm{H}$ & 119.6 & $736.0 \mathrm{ab}$ & $1,305.3 \mathrm{ab}$ & $2,174.5 \mathrm{a}$ \\
$\mathrm{I}$ & 158.3 & $617.4 \mathrm{~b}$ & $1,160.0 \mathrm{ab}$ & $1,563.2 \mathrm{ab}$ \\
\hline Tukey $\alpha 0,05$ & $\mathrm{~ns}$ & 438.4 & 704.8 & $1,086.3$ \\
\hline
\end{tabular}

Description: Numbers followed by the same letters in the same column, are not significantly different $(\mathrm{P}<0.05)$ using tukey range test.

Table 5. Effect of Combination of Type and Dosage of Organic Fertilizer on the Number of Tubers Per Clump, Tuber Diameter and Tuber Length of Plant.

\begin{tabular}{cccc}
\hline Treatment & $\begin{array}{c}\text { Number of tubers } \\
\text { (unit/clump) }\end{array}$ & Tuber diameter $(\mathrm{mm})$ & $\begin{array}{c}\text { Tuber lenght } \\
(\mathrm{cm})\end{array}$ \\
\hline $\mathrm{A}$ & $4.05 \mathrm{~b}$ & $9.53 \mathrm{~b}$ & $1.43 \mathrm{~b}$ \\
$\mathrm{~B}$ & $7.20 \mathrm{a}$ & $10.81 \mathrm{ab}$ & $2.13 \mathrm{a}$ \\
$\mathrm{C}$ & $5.55 \mathrm{ab}$ & $11.06 \mathrm{ab}$ & $2.11 \mathrm{a}$ \\
$\mathrm{D}$ & $5.90 \mathrm{ab}$ & $10.74 \mathrm{ab}$ & $2.37 \mathrm{a}$ \\
$\mathrm{E}$ & $5.75 \mathrm{ab}$ & $12.40 \mathrm{a}$ & $2.37 \mathrm{a}$ \\
$\mathrm{F}$ & $6.55 \mathrm{ab}$ & $11.94 \mathrm{ab}$ & $2.32 \mathrm{a}$ \\
$\mathrm{G}$ & $5.50 \mathrm{ab}$ & $12.87 \mathrm{a}$ & $2.41 \mathrm{a}$ \\
$\mathrm{H}$ & $5.85 \mathrm{ab}$ & $11.77 \mathrm{ab}$ & $2.28 \mathrm{a}$ \\
$\mathrm{I}$ & $6.80 \mathrm{a}$ & $11.48 \mathrm{ab}$ & $2.21 \mathrm{a}$ \\
\hline Tukey $\alpha 0,05$ & 2.72 & 2.81 & 0.59 \\
\hline
\end{tabular}

Description: Numbers followed by the same letters in the same column, are not significantly different $(\mathrm{P}<0.05)$ using tukey range test.

Table 6. Effect of Combination Treatment of Type and Dosage of Organic Fertilizer on Fresh Weight per tuber and Fresh Weight of Shallot Tuber per Hectare

\begin{tabular}{ccc}
\hline Treatment & $\begin{array}{c}\text { Fresh weight per tuber } \\
(\mathrm{g})\end{array}$ & $\begin{array}{c}\text { fresh weight of shallot tuber per } \\
\text { hectare (ton/ha) }\end{array}$ \\
\hline $\mathrm{A}$ & $0.91 \mathrm{~b}$ & $3.86 \mathrm{~b}$ \\
$\mathrm{~B}$ & $1.44 \mathrm{ab}$ & $5.69 \mathrm{ab}$ \\
$\mathrm{C}$ & $1.11 \mathrm{ab}$ & $5.22 \mathrm{ab}$ \\
$\mathrm{D}$ & $1.21 \mathrm{ab}$ & $5.40 \mathrm{ab}$ \\
$\mathrm{E}$ & $1.40 \mathrm{ab}$ & $6.32 \mathrm{a}$ \\
$\mathrm{F}$ & $1.56 \mathrm{a}$ & $7.63 \mathrm{a}$ \\
$\mathrm{G}$ & $1.20 \mathrm{ab}$ & $5.93 \mathrm{ab}$ \\
$\mathrm{H}$ & $1.17 \mathrm{ab}$ & $6.82 \mathrm{a}$ \\
$\mathrm{I}$ & $1.36 \mathrm{ab}$ & $5.66 \mathrm{ab}$ \\
\hline Tukey $\alpha 0,05$ & 0.53 & 2.43 \\
\hline
\end{tabular}

Description: Numbers followed by the same letters in the same column, are not significantly different $(\mathrm{P}<0.05)$ using tukey range test. 
Tuber Diameter. Various combinations of types and doses of fertilizers have a significant effect on the diameter of the shallot tuber of the 'lembah palu' varieties. The combination of type and dosage of organic fertilizer produced a larger tuber diameter and significantly different from treatment A (without organic fertilizer), but not significantly different from other treatments (Table 5).

Tuber Lenght. The treatment of various combinations of types and dosages of organic fertilizers significantly affected tuber length. In Table 5 it is shown that the combination treatment of types and doses of organic fertilizer produces a larger tuber diameter and is significantly different from treatment A (without organic fertilizer), whereas between types of treatment and other organic fertilizer doses are not significantly different. In addition to the type and dosage of organic fertilizer; the length of shallot tuber besides being determined by varieties is also influenced by soil moisture content and temperature (Ansar, 2012).

Fresh Weight Per Tuber. Various combinations of types and doses of organic fertilizer have a significant effect on the fresh weight of the shallot tuber 'lembah palu' varieties. Various combinations of types and doses of organic fertilizer have a significant effect on the fresh weight per tuber of shallots. In Table 6 it is shown that treatment $\mathrm{F}$ (bokashi mixture of goat manure and shallot residues as much as 20 ton/ha) produces greater fresh weight per tuber and significantly different from treatment A (without organic fertilizer), while between types and doses of fertilizer other organics are not significantly different from the fresh weight per tuber.

Fresh Weight of Tuber Per Hectare. The treatment of various combinations of types and doses of organic fertilizer significantly affected the fresh weight of tubers per hectare. In Table 6 shows that treatment $\mathrm{F}$ (bokashi mixture of goat manure and shallot waste as much as 20 ton/ha) produces the highest fresh weight of tuber per hectare (7,628 ton/ha) and is significantly different from treatment A (without organic fertilizer), but not different significant with other treatments.

\section{CONCLUSION}

The combination of types and doses of organic fertilizer in general results in higher growth and yield of shallots compared to the treatment without application of organic fertilizer. The combination of solid organic fertilizer (bokashi mixture goat manure 20 ton/ha and shallot residue 20 ton/ha) produce fresh weight per tuber and fresh weight of tuber per hectare is highest and significantly different from without organic fertilizer.

\section{REFERENCES}

Adrizal dan Jalid N. 1995. Pengaruh sumber bahan organic dan anorganik terhadap pertumbuhan dan hasil kacang tanah. Risalah Seminar BalitanSukarami. 8:162-167.

BPTP Sulteng. 2004. Satu Dasawarsa Balai Pengkajian Teknologi Pertanian (BPTP) Sulawesi Tengah. Balai Pengkajian Teknologi Pertanian (BPTP) Sulawesi Tengah, Pusat Penelitian dan Pengembangan Sosial Ekonomi Pertanian, Badan Penelitian dan Pengembangan Pertanian, Departemen Pertanian. Jakarta.

Cao and Min. 1995. Ecological Management of Degraded Lands in Upland Agriculture. Kunming, China.

Gardner F.P, Brent Pearce R. and Mitkhell L. 1991. Fisiologi Tanaman Budidaya. Susilo H., penerjemah. Jakarta: UI Press. Terjemahan dari: Physiology of Crop Plants. 
Gomez K.A. andGomez A.A., 1995. Prosedur Statistik untuk Penelitian Pertanian. Edisi ke-2. Syamsudin E. dan Baharsjah J.S., penerjemah. Jakarta: UI Press. Terjemahan dari: Statistical Proceduresfor Agricultural Reserach.

IndrianiY.H. 2001.Membuat Kompos Secara Kilat. Penebar Swadaya, Jakarta.

Khandakar A.L. 1994. Manual Of Methodes For Physio-Morphological Studies Of Jute, Kenaf And Allied Germplasm. International Jute Organisation. Dhaka, Bangladesh. p11-15.

[Kementan] Kementerian Pertanian. 2011. Surat KeputusanPelepasanVarietas 'Lembah Palu' sebagai Varietas Unggul Bawang Merah. Kementerian Pertanian Republik Indonesia. Jakarta.

Ansar M. 2012. Pertumbuhan dan Hasil Bawang Merah pada Keragaman Ketinggian Tempat. Disertasi. Universitas Gajah Mada. Yogyakarta.

Ansar M, Bahrudin dan I. Wahyudi. 2013. Modifikasi lingkungan mikro menggunakan sungkup plastik dan mulsa terhadap pertumbuhan dan hasil bawang merah varietas lembah palu pada agroekosistem lahan sawah. J. Agroland. 20(2):82-89.

Ansar M, Bahrudin dan I. Wahyudi. 2013b.Waktu pemberian air kincir, pupuk organik dan mulsa terhadap pertumbuhan dan hasil bawang merah varietas 'lembah palu'.Prosiding Seminar Nasional Pertanian. Palu, Desember 2013.

Ansar M, Bahrudin dan I. Wahyudi, 2014. Pengujian Pemupukan Spesifik Pada Kondisi Agroekosistem Lahan Kering Sentra Pengembangan Bawang Merah Varietas Lembah Palu.Prosiding Seminar NasionalUniversitas Brawijaya.Malang, 5-7 November 2014.

Sukamto H. 2007. Membuat Pupuk Kompos Cair. Agromedia Pustaka, Jakarta.

Sutanto, R. 2002. PertanianOrganik: Menuju Pertanian Alternatif dan Berkelanjutan. Kanisius. Yogyakarta.

Yang S.S. 2001. Recent Advances in Composting. In the Proceeding of Issues in the Management of Agricultural Resources. Food \& Fertilizer Technology Center, Taiwan, ROC.

\section{ACKNOWLEDGEMENT}

The authors would like to express their gratitude to the Directorate of Research and Community Service, Director General of Research and Development Strengthening, Ministry of Research, Technology and Higher Education of the Republic of Indonesia for the support and facilitation of research funding through the Higher Education Applied Research Scheme (PTUPT) at the Research and Community Service Institution Tadulako University. 